\title{
Deficiency of essential elements in volcanic soils: potential harmful health effects on grazing cattle
}

\author{
Diana Linhares $(\mathbb{D} \cdot$ Adriano Pimentel $\cdot$ Patrícia Garcia $\cdot$ Armindo Rodrigues
}

Received: 11 August 2020/ Accepted: 27 February 2021

(C) The Author(s), under exclusive licence to Springer Nature B.V. 2021

\begin{abstract}
Several essential nutrients such as Fe, Co, $\mathrm{Cu}, \mathrm{I}, \mathrm{Se}$, and $\mathrm{Zn}$ are vital to grazing cattle as they play a significant role in intracellular enzyme systems, with antioxidant and repair functions of DNA lesions. Feeds may supply most essential nutrients in adequate amounts. However, essential nutrient deficiencies are common and are mainly related to the geochemical characteristics of the soils, inherited from parent rocks. This study aims to assess the concentrations of the selected essential nutrients in topsoils and pasture grass from São Miguel Island (Azores) and discuss the possible effects of its deficiency in grazing cattle health. Sixty-eight samples of agricultural (pastures) topsoil and thirty samples of pasture grass were collected throughout São Miguel Island in areas with basaltic and trachytic parent rocks. Soil
\end{abstract}

D. Linhares $(\varangle) \cdot$ A. Pimentel · A. Rodrigues

IVAR, Research Institute for Volcanology and Risk Assessment, University of the Azores, Rua da Mãe de Deus, Apartado 1422, 9501-801 Ponta Delgada, Açores, Portugal

e-mail: diana.ps.linhares@uac.pt

A. Pimentel

CIVISA, Centre for Information and Seismovolcanic

Surveillance of the Azores, 9501-801 Ponta Delgada, Portugal

\section{A. Pimentel}

InBIO Associate Laboratory, CIBIO, Research Centre in Biodiversity and Genetic Resources, Pole of the Azores, 9501-801 Ponta Delgada, Portugal physicochemical properties and geochemical baselines of selected elements were determined on composite samples of soil and pasture grass in each site. Results indicate that the highest concentrations of the selected essential nutrients were observed in areas with basaltic soils, while the lowest values were found in areas with trachytic soils. These differences are considered of geogenic origin since they result from the weathering of volcanic parent rocks with different geochemical compositions. Data indicate a lack of some essential nutrients in topsoils (Co and Se) and/or pasture grass $(\mathrm{Co}, \mathrm{Cu}, \mathrm{Se}$, and $\mathrm{Zn})$ that can contribute to harmful health effects on grazing cattle. The uneven distribution of essential nutrients in topsoil and pasture grass and their deficiency can lead to several health problems in the cattle since these elements regulate

P. Garcia · A. Rodrigues

Faculty of Sciences and Technology, University of the Azores, 9501-801 Ponta Delgada, Portugal

P. Garcia

CE3C, Centre for Ecology, Evolution and Environmental Changes, and Azorean Biodiversity Group, University of the Azores, 9501-801 Ponta Delgada, Portugal 
physiological functions in biological systems. The identification of these deficit sites is important as it can help farmers to implement soil and/or animal supplementation programs to diminish possible health problems.

Keywords Geochemistry · Essential elements . Volcanism · Bioavailability $\cdot$ Azores

\section{Introduction}

Soil is the main source of nutrients for plants, animals, and humans (Kelepertsis et al., 2001). The concentration of essential elements in the soil may affect plant uptake, influencing the concentration of certain elements in fodder crops, water and, that in turn may have effects on animal and human health (Senesi et al., 1999).

The geochemical characteristics of soils are mostly inherited from the parent rocks and percolating fluids (Aiuppa et al., 2000; Cruz et al., 1999; Marescotti et al., 2019; Thornton \& Alloway, 1974). However, soil composition also depends on the climate, weathering processes, biological activity, and its age (Freitas $\&$ Pacheco, 2010). Soils may be enriched or depleted in certain chemical elements by different pathways. The most common via of enrichment is by anthropogenic activity such as commercial fertilizers, agrochemicals, and sewage sludge (Adriano, 1986; Aranalds et al., 2007), but geogenic sources, such as volcanism, can also contribute to different concentrations of certain elements in the soil (Bargagli et al., 1991; Aiuppa et al., 2000; Neal et al., 2006; Neta, 2018).

Volcanic parent rocks and volatiles are responsible for the enrichment of essential elements in soils (Amaral et al., 2006; Bargagli et al., 1991; Doelsch et al., 2006; Freitas \& Pacheco, 2010; Parelho et al., 2014); also, volcanic ash emissions blown by the wind enable the dispersion of trace elements over long distances (Tepe \& Bau, 2014). Although volcanic soils represent $1 \%$ of the Earth's surface, they support approximately $10 \%$ of the worldwide population.

There are at least 15 mineral elements that are considered essential to grazing cattle, the macrominerals such as calcium $(\mathrm{Ca})$, chlorine $(\mathrm{Cl})$, phosphorus $(\mathrm{P})$, magnesium $(\mathrm{Mg})$, potassium $(\mathrm{K})$, sodium $(\mathrm{Na})$, and sulfur (S), and the micromineral elements such as cobalt $(\mathrm{Co})$, copper $(\mathrm{Cu})$, iron $(\mathrm{Fe})$, iodine $(\mathrm{I})$, manganese $(\mathrm{Mn})$, selenium (Se), zinc $(\mathrm{Zn})$, and molybdenum (Mo) (Judson \& McFarlane, 1998; Prasad et al., 1995). The deficiency or excess of these elements in the soil causes several health problems on grazing cattle. Several essential nutrients such as Fe, $\mathrm{Co}, \mathrm{Cu}, \mathrm{I}, \mathrm{Se}$, and $\mathrm{Zn}$ have different physiological functions although all are involved in the immune system (Djoko et al., 2015; Meglia, 2004). This is an issue that assumes an increasing importance as the livestock sector has a primary and growing role in the agriculture economy. Even though the optimal concentrations in which these nutrients must be provided to livestock depend on the development stage of the animal and the production cycle, their importance is well known (Peers and Philips, 2011; López-Alonso, 2012). Yet, the role of essential nutrients is often underestimated and their presence in the feeds in adequate quantities is taken for granted, resulting in a deficient intake by the grazing cattle.

The deficient intake of essential nutrients by the gazing cattle has a worldwide distribution as reported by several studies. In New Zealand, marginal deficiencies of $\mathrm{Co}, \mathrm{Cu}, \mathrm{I}$, and $\mathrm{Se}$ have been shown to result in poor animal performance and a decrease in farm profitability (Grace, 1994). In England and Wales, the main cause of different essential element deficiencies has been attributed to variable geomorphology and soils. It has been shown that deficiencies occur in areas where the soil cannot supply sufficient essential elements to the plants that animals feed on (Lark et al., 2014; Rawlins et al., 2012).

In the Azores, where agricultural systems are mainly based on pastures for dairy cows, the deficiency of some essential nutrients such as $\mathrm{Co}, \mathrm{Cu}, \mathrm{I}$, $\mathrm{Se}$, and $\mathrm{Zn}$ has been related to the way these elements are exploited in permanent grazing areas with volcanic soils (Pinto et al., 2007a, 2007b). More recently, Linhares et al. (2019) demonstrated that in São Miguel Island there is a significant lack of Co in trachytic agricultural topsoils and pasture grass when compared with basaltic soils, which is attributed to the pedogenesis of parent volcanic rocks with different compositions.

Bearing in mind that (1) soil elemental composition may have a significant effect on animal health, and (2) several essential nutrients such as $\mathrm{Fe}, \mathrm{Co}, \mathrm{Cu}, \mathrm{I}, \mathrm{Se}$, and $\mathrm{Zn}$ play a fundamental role in different 
physiological functions, including the immune system of grazing cattle, this study aims to determine their deficiency and/or excess and assess the availability of these essential nutrients in topsoils and pasture grass from São Miguel Island. In view of the results, the possible health effects in livestock are discussed and, when possible, proposals to reduce the negative health impact of geological conditions in volcanic areas are given.

\section{Material and methods}

Study area

São Miguel Island is the largest $\left(744 \mathrm{~km}^{2}\right)$ and the most populated (137,000 inhabitants) of the Azores archipelago, located in the North Atlantic Ocean, approximately $1400 \mathrm{~km}$ west of mainland Portugal (inset of Fig. 1). São Miguel is formed by three active central volcanoes (Sete Cidades, Fogo, and Furnas), two active fissure systems (Picos and Congro) and two extinct volcanic systems (Povoação and Nordeste) (Fig. 1; Gaspar et al., 2015; Pacheco et al., 2013).

The recent geological record (i.e., last 5000 years) of São Miguel reveals that volcanism was dominated by the activity of Sete Cidades, Fogo, and Furnas central volcanoes, marked by trachytic explosive eruptions that produced widespread pyroclastic deposits. During the same period, the eruptive activity of Picos and Congro fissure systems was characterized by basaltic eruptions that produced lava flows and scoria cones. On the other hand, Povoação and Nordeste volcanic systems were not active during the last 10,000 years (Gaspar et al., 2015; Pacheco et al., 2013).

In Sete Cidades, Fogo and Furnas soil parent materials are young $(<5000$ years $)$ felsic pyroclastic rocks with a trachytic composition $\left(\mathrm{SiO}_{2}>62 \mathrm{wt} \%\right.$; $\mathrm{Na}_{2} \mathrm{O}+\mathrm{K}_{2} \mathrm{O}>10.8$ wt\%; Fig. 2). However, the bedrocks in Fogo and Furnas tend to be slightly more evolved peralkaline trachytes (Jeffery et al., 2016; Wallenstein, 1999) when compared to Sete Cidades (Queiroz, 1997). By contrast, Picos and Nordeste soil parent rocks (lava or scoria) are mafic with compositions ranging from basaltic to trachybasaltic $\left(\mathrm{SiO}_{2-}\right.$ $<50.6$ wt $\% ; \quad \mathrm{Na}_{2} \mathrm{O}+\mathrm{K}_{2} \mathrm{O}<6.4$ wt $\% ; \quad$ Fig. 2) (Beier et al., 2007; Zanon, 2015). It should be noted that the bedrocks in Picos are typically younger than
5000 years, while in Nordeste are older than 10,000 years. In Congro soil, parent rocks are windblown trachytic pyroclasts from the adjacent Fogo and Furnas volcanoes, despite Congro being an active basaltic fissure system (but with low eruptive frequency). Also, Povoação soil parent rocks are, in most cases, trachytic pyroclasts blown from the neighboring Furnas volcano (Linhares et al., 2019).

The trachytic parent rocks of São Miguel are characterized by major element compositions with low concentrations of $\mathrm{CaO}, \mathrm{MgO}, \mathrm{FeO}, \mathrm{TiO}_{2}$, and $\mathrm{P}_{2} \mathrm{O}_{5}$, high concentrations of $\mathrm{K}_{2} \mathrm{O}, \mathrm{Na}_{2} \mathrm{O}$, and $\mathrm{Al}_{2} \mathrm{O}_{3}$, and variable $\mathrm{MnO}$. Several trace elements such as $\mathrm{Co}$, $\mathrm{Cr}, \mathrm{Cu}, \mathrm{Ni}$, and $\mathrm{V}$ also have low concentrations, and other like $\mathrm{Zn}$ and Mo have variable concentrations. By contrast, the basaltic/trachybasaltic parent rocks show opposite behaviors for the same elements (Fig. 3).

The soils of São Miguel correspond to Andisols (Amaral et al., 2006; Freitas \& Pacheco, 2010; Madeira et al., 2007; Ricardo et al., 1977), with Udands as the dominant suborder. The distribution and characteristics of Udands are related to the age and nature of parent rocks, but also to the amount of precipitation and soil moisture regime, which depends on altitude. On the other hand, Udivitrands develop on trachytic and basaltic pyroclastic materials and can be found at any altitude (Madeira et al., 2007).

São Miguel Island has a temperate oceanic climate, (group C) according to Köppen's classification, with no dry season and a mild/hot summer. It is characterized by mild temperatures with small annual variations (average annual air temperature is $17.5^{\circ} \mathrm{C}$ in coastal areas) and a rainfall regime with strong seasonal cycle and large inter-annual variability (average annual precipitation can reach up to $3197 \mathrm{~mm}$ in high grounds), although these are strongly influenced by altitude and topography (Chazarra et al., 2011; Cropper, 2013; Hernández et al., 2016).

Soil and pasture grass sampling

A total of 68 samples of agricultural (pastures) topsoil and 30 samples of pasture grass were collected in São Miguel Island (Fig. 1). The selected sites correspond to some of the main producers of dairy cattle in the island and were grouped according to the composition of soil parent rocks into trachytic and basaltic. Sampling sites located in Sete Cidades, Fogo, Congro, Furnas, and Povoação have trachytic parent rocks, 


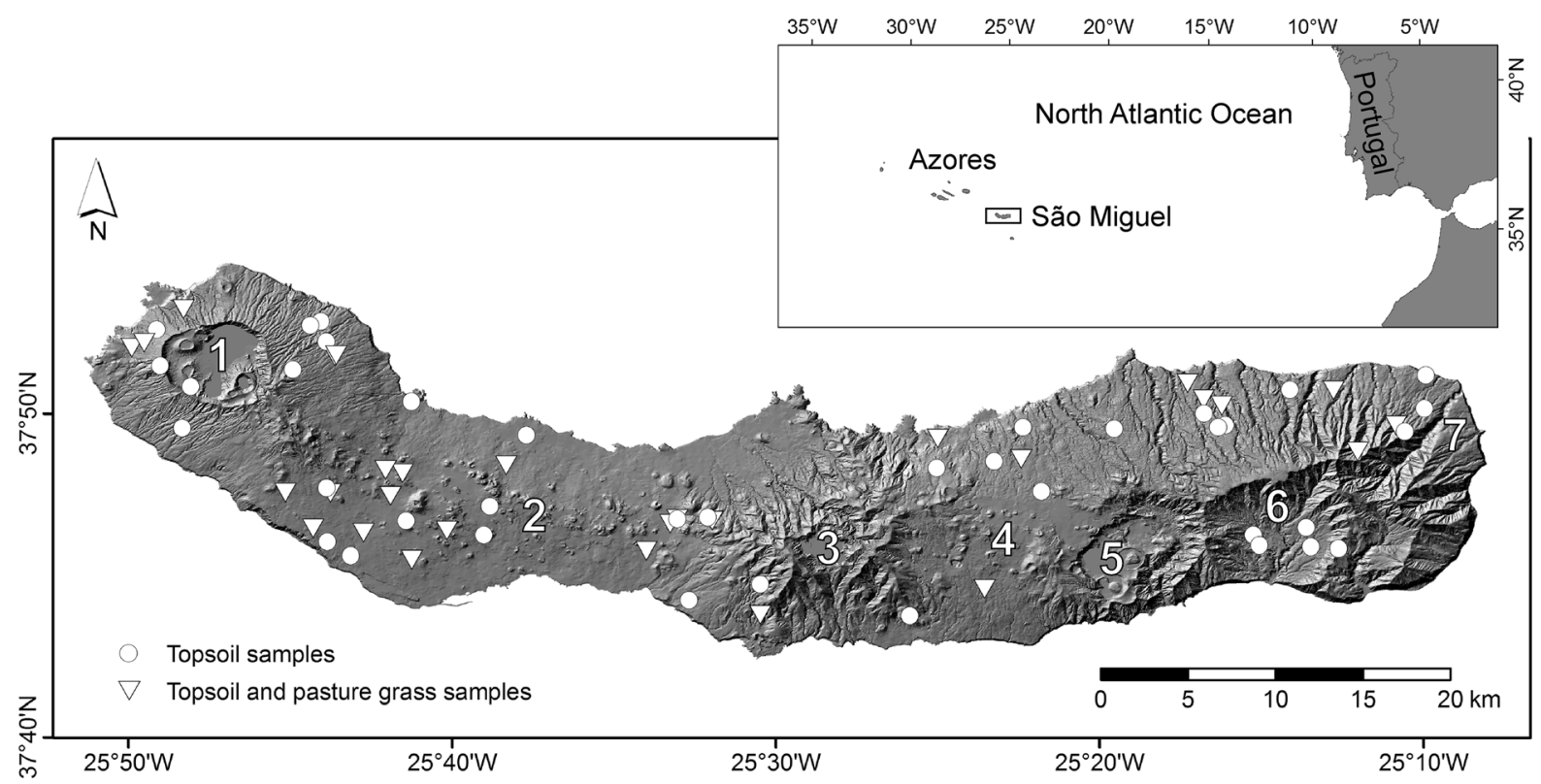

Fig. 1 Digital elevation model of São Miguel Island (Azores) showing the volcanic systems and the location of topsoil and pasture grass samples (1-Sete Cidades volcano; 2-Picos fissure system; 3-Fogo volcano; 4-Congro fissure system;
5-Furnas volcano; 6-Povoação volcano; 7-Nordeste volcanic system; Gaspar et al. [28]). Inset shows the location of the Azores archipelago in the North Atlantic Ocean

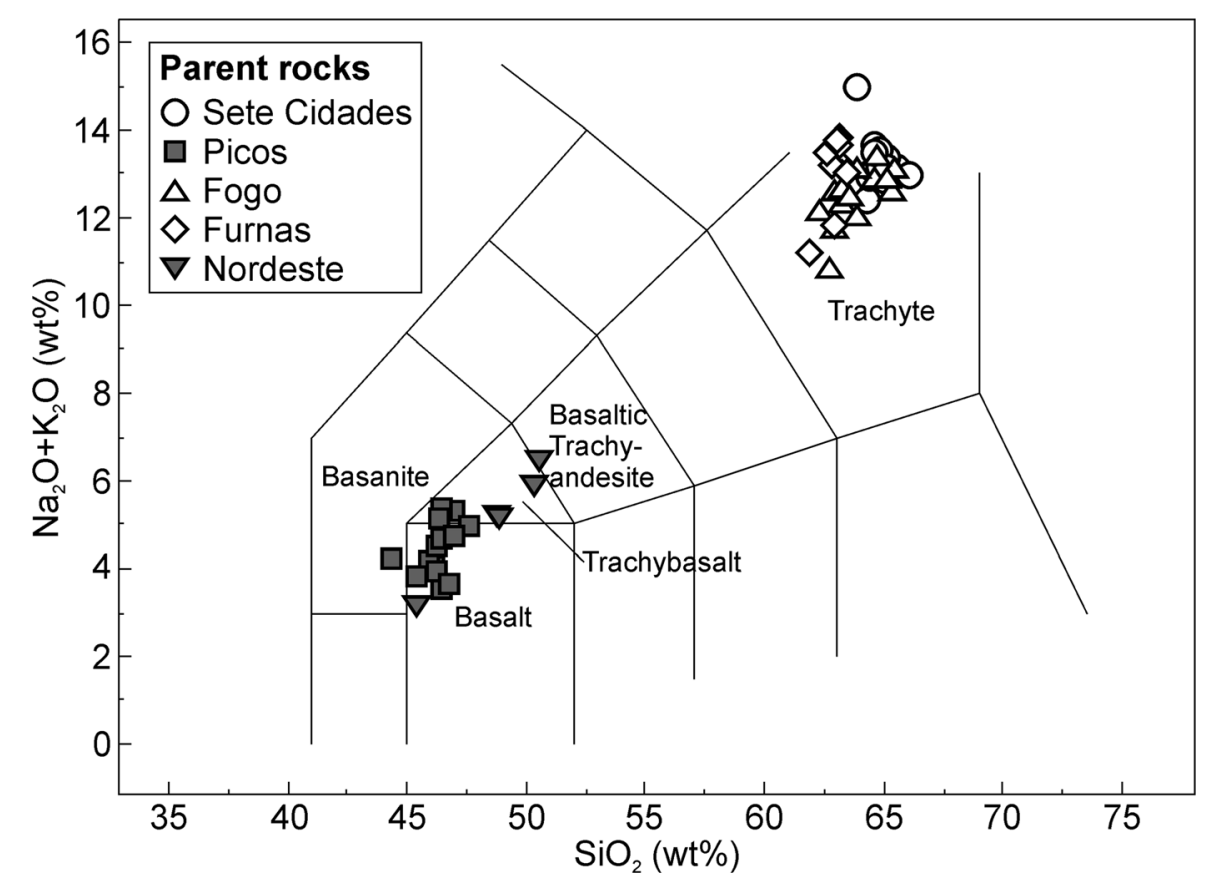

Fig. 2 Total alkali-silica (TAS) diagram [71] for the classification of soil parent rocks of São Miguel Island (Azores). All data sourced from Queiroz [31], Wallenstein [29], Beier et al. [32], Zanon [33], and Jeffery et al. [30] 

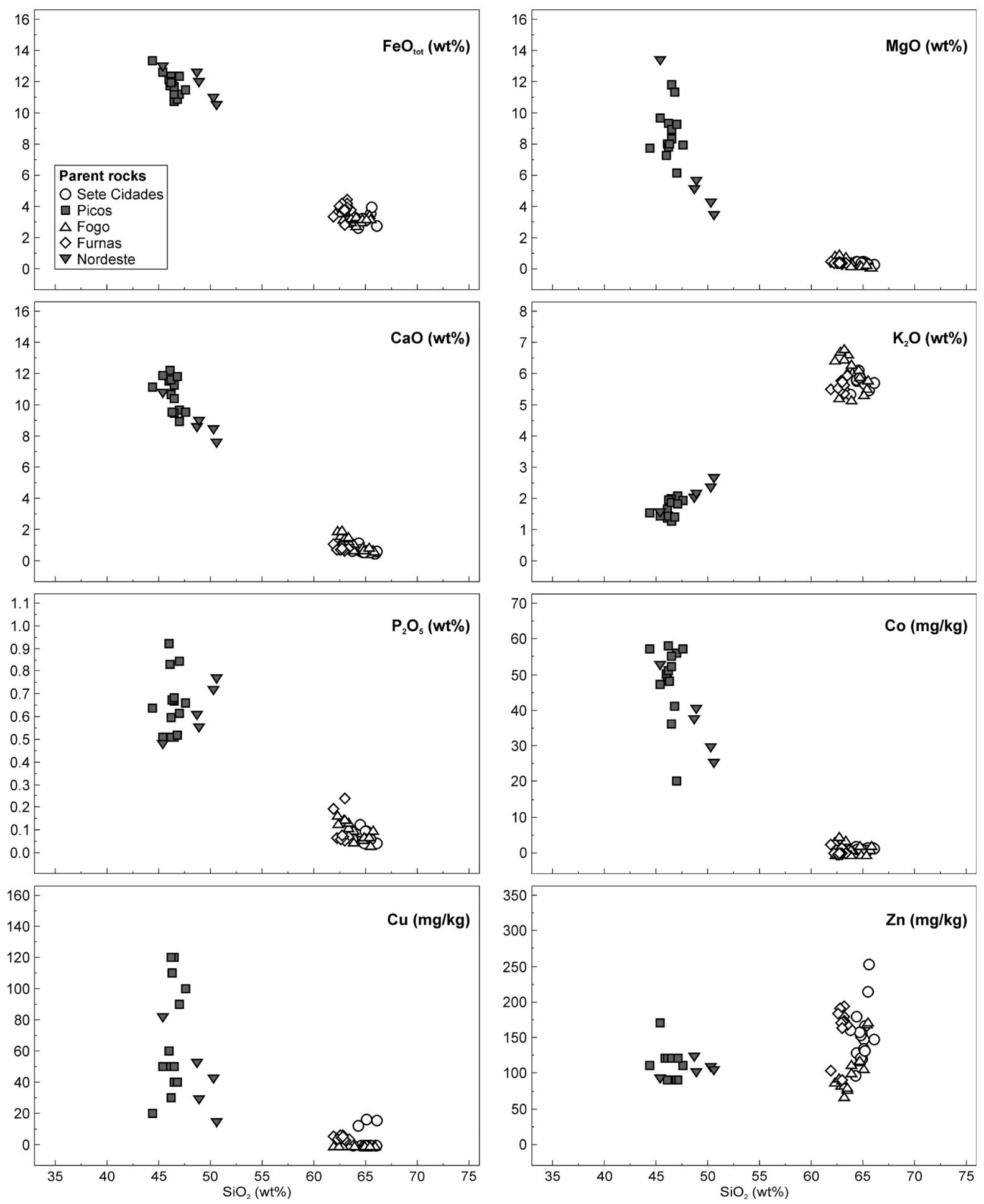

Fig. 3 Variation diagrams of representative major and trace elements plotted versus silica for soil parent rocks of São Miguel Island (Azores). Basaltic rocks plotted as gray symbols and trachytic rocks plotted as white symbols. The content of some

trace elements is below the detection limit. All data sourced from Queiroz [31], Wallenstein [29], Beier et al. [32], Zanon [33], and Jeffery et al. [30] 
whereas sites located in Picos and Nordeste have basaltic parent rocks. The collection of topsoil and pasture grass samples occurred only once and simultaneously in each site, between April and July 2018.

Topsoil samples (42 from trachytic parent rocks and 26 from basaltic parent rocks) were collected as described in the GEMAS field protocol (GEMAS, 2008). Composite soil samples [defined by a square $\left(1 \mathrm{~m}^{2}\right)$ with four collecting points in the vertices and one collecting point in the center] were collected in each sampling site with a spiral hand auger up to a maximum depth of $10 \mathrm{~cm}$, after removal of surface litter. The composite samples were divided into two subsamples: one to determine soil physicochemical properties and the other for the elemental analyses.

Pasture grass samples (15 from trachytic soil parent rocks and 15 from basaltic soil parent rocks) were collected following the same methodology described above for composite soil samples. The time for sampling was defined according to the phenological status of the pasture grass: sample collection occurred on the 3rd and 4th days of cattle grazing in pastures grown for at least 4 weeks. Although the grazing pastures may have different species of plants, only the most abundant ones were collected. The aerial parts of Lolium multiflorum and Holcus lanatus were considered for analysis ( $200 \mathrm{~g}$ per sampling site), but their roots were discarded. Rumex obtusifolius was discarded because this plant species is not consumed by the grazing cattle; any other species sporadically present in the grazing pastures, such as Trifolium repens and Racunulus repens, was also discarded.

\section{Soil physicochemical properties}

The measurement of the $\mathrm{pH}$ and the electrical conductivity was performed in situ using a portable meter (HI99121 Hanna Instruments). In the laboratory, composite soil samples were mixed and divided into two subsets. One set was oven-dried at $60{ }^{\circ} \mathrm{C}$ until a constant weight was achieved and soil organic matter was determined by soil oxidation with hydrogen peroxide $\left(\mathrm{H}_{2} \mathrm{O}_{2}\right)$, following Jackson (1958) methodology. The second set was used to determine soil organic carbon by wet oxidation with $1 \mathrm{~N}$ potassium dichromate Walkley-Black procedure, according to Nelson and Sommers (1982); three replicates were performed per sample.
Soil and pasture grass elemental analysis

Topsoil samples were sieved down to $2 \mathrm{~mm}$ and ovendried at $60{ }^{\circ} \mathrm{C}$ until constant weight was achieved. Pasture grass samples were washed with distilled water, cut into small fractions, and oven-dried at $60{ }^{\circ} \mathrm{C}$ until constant weight.

Major and trace elements in topsoil and pasture grass were determined at Actlabs (Activation Laboratories Ltd., Canada) by inductively coupled plasma mass spectrometry (ICP-MS), after digestion in aqua regia. The analysis of duplicate samples, blanks, and reference materials (GXR-4 and GXR-6) assured quality control. Actlabs is an accredited (ISO 17025) and certified laboratory (ISO 9001:2008). Further information on the analytical methods is available at the Actlabs website (www.actlabs.com).

The elements known to play a significant role in intracellular enzyme systems, with antioxidant and repair functions of DNA lesions ( $\mathrm{Fe}, \mathrm{Co}, \mathrm{Cu}, \mathrm{I}, \mathrm{Se}$, and $\mathrm{Zn}$ ) were considered in this study.

\section{Statistical analysis}

The Kruskal-Wallis was used to test for differences between datasets and, when significant $(p<0.05)$, the Mann-Whitney $U$ test was used for pairwise comparisons. All statistical analyses were performed using IBM SPSS Statistics 26.0 for Windows (IBM SPSS, 2019).

\section{Results}

Soil physicochemical properties and essential elements

The physicochemical properties of soils from trachytic and basaltic parent rocks are similar, with the exception of the organic carbon concentration that showed significant differences between the two types of soils (Table 1). Basaltic soils had a higher percentage of organic carbon $(3.57 \% \pm 0.22)$ when compared with trachytic soils $(2.76 \% \pm 0.24)$.

All considered essential elements showed significant differences between the two types of soils, except for Se that had a similar distribution in basaltic and trachytic soils $(p=0.770)$ (Table 1). Essential elements had consistently higher mean values in basaltic 
Table 1 Mean values ( \pm SE) of soil physicochemical properties and essential nutrients from São Miguel (Azores) according to parent rock composition. Reference values for $\mathrm{Fe}, \mathrm{Co}, \mathrm{Cu}, \mathrm{I}$, Se, and $\mathrm{Zn}$ studies are also shown

\begin{tabular}{|c|c|c|c|c|}
\hline & Trachytic $(n=42)$ & Basaltic $(n=26)$ & $p$ value $^{\mathrm{a}}$ & Reference values \\
\hline \multicolumn{5}{|l|}{ Physicochemical properties } \\
\hline $\mathrm{pH}$ & $5.82 \pm 0.07$ & $5.84 \pm 0.08$ & 0.776 & \\
\hline Organic matter $(\%)$ & $1.93 \pm 0.12$ & $2.19 \pm 0.16$ & 0.119 & \\
\hline Electrical conductivity $(\mathrm{mS} / \mathrm{cm})$ & $0.09 \pm 0.01$ & $0.11 \pm 0.01$ & 0.248 & \\
\hline Organic carbon $(\%)$ & $2.76 \pm 0.24$ & $3.57 \pm 0.22$ & 0.001 & \\
\hline \multicolumn{5}{|l|}{ Macroelements (\%) } \\
\hline $\mathrm{Fe}$ & $1.60 \pm 0.10$ & $3.05 \pm 0.19$ & $<0.001$ & $2.17^{\mathrm{b}}$ \\
\hline \multicolumn{5}{|l|}{ Microelements (mg/kg) } \\
\hline Co & $3.48 \pm 0.53$ & $10.84 \pm 1.13$ & $<0.001$ & $8.91^{\mathrm{b}}$ \\
\hline $\mathrm{Cu}$ & $10.26 \pm 1.81$ & $28.28 \pm 3.43$ & $<0.001$ & $10-32^{c}$ \\
\hline I & $20.63 \pm 2.01$ & $30.59 \pm 2.27$ & $<0.001$ & $2.7-26.3^{\mathrm{d}}$ \\
\hline $\mathrm{Se}$ & $0.42 \pm 0.07$ & $0.43 \pm 0.06$ & 0.770 & $0.4^{\mathrm{e}}$ \\
\hline $\mathrm{Zn}$ & $91.32 \pm 4.64$ & $147.81 \pm 7.62$ & $<0.001$ & $55-130^{\mathrm{c}}$ \\
\hline
\end{tabular}

${ }^{a} p$ value for group comparisons by: Kruskal-Wallis for all continuous variables followed by Mann-Whitney $U$ test

${ }^{\mathrm{b}}$ Salminen et al. (2005)

${ }^{\mathrm{c}}$ Gawlick \& Bidoglio (2006)

${ }^{\mathrm{d}}$ Linhares et al. (2015)

${ }^{\mathrm{e}}$ Kabata-Pendias (2011)

soils when compared with trachytic soils: $\mathrm{Fe}$ $(3.05 \% \pm 0.19$ vs. $1.60 \% \pm 0.10) ;$ Co $(10.84 \mathrm{mg} /$ $\mathrm{kg} \pm 1.13$ vs. $3.48 \mathrm{mg} / \mathrm{kg} \pm 0.13) ; \mathrm{Cu}(28.28 \mathrm{mg} /$ $\mathrm{kg} \pm 3.43$ vs. $10.26 \mathrm{mg} / \mathrm{kg} \pm 1.81) ; \mathrm{I} \quad(30.59 \mathrm{mg} /$ $\mathrm{kg} \pm 2.22$ vs. $20.65 \mathrm{mg} / \mathrm{kg} \pm 2.01) ; \mathrm{Zn}(147.81 \mathrm{mg} /$ $\mathrm{kg} \pm 7.62$ vs. $91.32 \mathrm{mg} / \mathrm{kg} \pm 4.64$ ) (Table 1). Reference values for these essential elements in soils are given in Table 1.

Essential elements in pasture grass

Significant differences were found in pasture grass from trachytic and basaltic soils for $\mathrm{Co}$ and $\mathrm{Cu}$ distribution ( $p=0.048$ and $p=0.007$, respectively). The highest values were observed in pasture grass from basaltic soils (Table 2). All other elements had a similar distribution in pasture grass from trachytic and basaltic soils, but the highest values were always found in basaltic soils (Table 2). Reference values for $\mathrm{Fe}, \mathrm{Cu}$, and $\mathrm{Zn}$ in plants are given in Table 2 .

The concentrations of essential elements in pasture grass show that the availability of $\mathrm{Cu}, \mathrm{Se}$, and $\mathrm{Zn}$ is not enough to fulfill the needs of cattle grazing in both trachytic and basaltic soils (Table 2). The availability of Co in pasture grass is only adequate to cattle requirements when grazing in basaltic soils $(0.13 \mathrm{mg} /$ $\mathrm{kg} \pm 0.06$ ) (Table 2).

\section{Discussion}

Our results show that the pasture topsoils of São Miguel Island are similar in terms of $\mathrm{pH}$, soil organic matter and electrical conductivity, but show significant differences for the organic carbon concentration. Soils from basaltic parent rocks have significantly higher concentrations of organic carbon when compared with soils from trachytic parent rocks. This difference may be due to agricultural land use, as the most productive farms are located in areas with basaltic soils and adding off-farm organic residues can increase soil organic carbon. Similar results were observed in other pasture areas (Linhares et al., 2019; Parelho et al., 2014). In general, the percentage of organic carbon in volcanic ash soils (Andisols) is in the order of 5\% (Eswaran et al., 1993); however, our 
Table 2 Mean values ( \pm SE) of essential nutrients in pasture grass from São Miguel (Azores) according to soil parent rock composition. Reference values for the essential elements in pasture grass and the adequate concentrations to supply cattle needs are also shown

\begin{tabular}{lcclll}
\hline Essential nutrients $(\mathrm{mg} / \mathrm{kg})$ & Trachytic $(n=15)$ & Basaltic $(n=15)$ & $p$ value ${ }^{\mathrm{a}}$ & Reference values & $\begin{array}{l}\text { Adequate concentration for } \\
\text { supplying cattle needs }(\mathrm{mg} / \mathrm{kg})\end{array}$ \\
\hline $\mathrm{Fe}$ & $188.89 \pm 32.09$ & $285.45 \pm 84.90$ & 0.367 & $20^{\mathrm{b}}$ & $>50^{\mathrm{d}}$ \\
$\mathrm{Co}$ & $0.06 \pm 0.02$ & $0.13 \pm 0.06$ & 0.048 & No data & $>0.1^{\mathrm{e}}$ \\
$\mathrm{Cu}$ & $7.72 \pm 0.64$ & $9.28 \pm 0.29$ & 0.007 & $10^{\mathrm{c}}$ & $>10^{\mathrm{d}}$ \\
$\mathrm{I}$ & $8.63 \pm 1.50$ & $7.68 \pm 1.05$ & 0.838 & No data & $>0.5^{\mathrm{f}}$ \\
$\mathrm{Se}$ & $0.1 \pm 0.006$ & $0.14 \pm 0.03$ & 0.234 & No data & $>0.2^{\mathrm{d}}$ \\
$\mathrm{Zn}$ & $32.15 \pm 1.74$ & $33.60 \pm 1.30$ & 0.436 & $0.60^{\mathrm{c}}$ & $>40^{\mathrm{d}}$ \\
\hline
\end{tabular}

${ }^{\mathrm{a}} p$ value for group comparisons by: Kruskal-Wallis for all continuous variables followed by Mann-Whitney $U$ test

${ }^{\mathrm{b}} \mathrm{WHO}(1998)$

${ }^{\mathrm{c}} \mathrm{WHO}(1996)$

${ }^{\mathrm{d}}$ Mortimer et al. (1999)

${ }^{\mathrm{e}}$ Coulter and Lalor (2008)

${ }^{\mathrm{f}}$ National Research Council(2001)

results show a much lower concentration of soil organic carbon. A high organic carbon concentration helps to maintain agricultural production as it raises fertility and increases the activity and diversity of soil biota. Furthermore, it promotes soil structure or tilth, resulting in greater physical stability that improves soil aeration and correct water drainage/retention, reducing the risk of erosion and nutrient leaching (Ehrmann \& Ritz, 2014).

Except for selenium, the selected essential elements $(\mathrm{Fe}, \mathrm{Co}, \mathrm{Cu}, \mathrm{I}$, and $\mathrm{Zn}$ ) show remarkable differences in their mean concentration values between trachytic and basaltic topsoils (Table 1). These can be explained by their geogenic origin, as these soils result from the weathering of volcanic parent rocks with different geochemical compositions, which are related to different degrees of magmatic differentiation. Less differentiated volcanic rocks, such as basalts and trachybasalts, have higher concentrations of $\mathrm{Fe}, \mathrm{Co}$, and $\mathrm{Cu}$ (see Fig. 3) when compared with more differentiated volcanic rocks like trachytes (Neall, 2006; Pimentel et al., 2016; Porreca et al., 2018). Still, when comparing our results with references values from other studies (Table 1), the selected essential elements are within the excepted range, except for: the Co concentration in trachytic soils, which is below the reference values; and the I and $\mathrm{Zn}$ concentrations in basaltic soils that are slightly above the reference values.

Soils and parent rocks are the primary sources of essential elements for plants and animals. It is recognized that the selected essential nutrients are required for the normal functioning of almost all biochemical processes, as they are part of numerous enzymes and are involved in several biological pathways, particularly in the immune system (Djoko et al., 2015; Meglia, 2004). Even marginal deficiencies of these elements in the soil can result in cattle health problems (Suttle, 2010). Our results clearly reveal an uneven distribution of these essential nutrients in the pasture soils of São Miguel Island. Therefore, the possible various health problems in grazing cattle resulting from their deficiency or excess (that may lead to toxicity) are further ahead discussed.

None of the considered elements showed concentrations substantially above the recommended levels in topsoils and therefore toxic health effects related to the exposure to excessive concentrations are not expected. In the pasture grass, Fe and $\mathrm{Zn}$ concentrations are higher than the reference values; nevertheless, we should consider that the plant species used to define the reference values are not the same as those found in the sampled pastures and that the sampling areas were not volcanic in origin. Therefore, one should be critical when comparing these values. 
Our results indicate that all grazing areas are deficient in $\mathrm{Se}(<0.6 \mathrm{mg} / \mathrm{kg}$ in topsoils and $0.2 \mathrm{mg} / \mathrm{kg}$ in pasture grass) and that areas with trachytic soils are deficient in Co $(<5 \mathrm{mg} / \mathrm{kg}$ in topsoils and $<0.1 \mathrm{mg} /$ $\mathrm{kg}$ in pasture grass). The soil deficiency in Se found in São Miguel may contribute to an inadequate animal dietary intake, as reported for many other parts of the world (Molnar et al., 1998). In selenium-deficient regions, such as New Zealand, Denmark, Canada, Finland, Sweden, and Germany, where the concentrations of Se in the soil are below $0.6 \mathrm{mg} / \mathrm{kg}$, the forages do not provide adequate dietary Se for livestock (Gupta \& Gupta, 2002). This situation is also observed in our study as the Se concentration in pasture grass is below $0.2 \mathrm{mg} / \mathrm{kg}$, which is not adequate to fulfill the grazing cattle needs for maintaining blood Se concentration above the typical guideline value of $0.1 \mathrm{mg} /$ g blood (Fordyce, 2005). Deficient intake of Se contributes to the development of several diseases, such as the white muscle disease, which results in degeneration and necrosis of skeletal and cardiac muscle, reduced daily gain and immune function, as well as poor reproduction due to increased incidence of early embryonic death and retained placentas (Surai, 2006).

The Co concentrations below $5 \mathrm{mg} / \mathrm{kg}$ in trachytic soils reinforce the results obtained by Linhares et al. (2019). Along with the fact that a minimum concentration of Co in pasture grass of $0.1 \mathrm{mg} / \mathrm{kg}$ is required to meet the needs of adult cattle (Mortimer et al., 1999), these results confirm that the animals grazing in areas with trachytic soils lack adequate Co intake. This Co deficiency leads to the need to implement mitigation programs to prevent vitamin $\mathrm{B}_{12}$ deficiency and associated health problems, in particular pernicious anemia and nerve damage (Dangour et al., 2015; Tun et al., 2017; Yadav et al., 2016).

This study also evidenced that $\mathrm{Cu}$ and $\mathrm{Zn}$ concentrations in pasture grass of São Miguel are insufficient to fulfill the animal's needs and, therefore, can lead to several health problems in the cattle. Even though $\mathrm{Cu}$ had near adequate concentrations in the soils, its availability in pasture grass is very low. This can be explained because organic matter decreases $\mathrm{Cu}$ availability for plants (Mcdowell, 2003). As cattle require at least $10 \mathrm{mg} / \mathrm{kg}$ of $\mathrm{Cu}$ and the recommended levels for cows in late pregnancy and rapidly growing yearlings are above $20 \mathrm{mg} / \mathrm{kg}$ (Mortimer et al., 1999), it is expected that without any additional supplementation (e.g.: forages, oral supplements) the grazing animals in São Miguel may suffer from hypocupremia, a well recognized and widespread potential problem in cattle worldwide (Dargatz et al., 1999; Mattioli et al,. 1996; Pavlata et al., 2005). Inadequate $\mathrm{Cu}$ intake affects several biological processes, including red blood cell production and iron absorption from the small intestine, resulting in anemia after prolonged and/or severe periods of $\mathrm{Cu}$ deficiency (McDowell, 1985); furthermore, an inadequate intake of $\mathrm{Cu}$ is also associated with reduced fertility due to depressed or delayed oestrus behavior, particularly in heifers (Kreplin \& Yaremcio, 1992; Torre et al., 1996).

Our results also indicate that $\mathrm{Zn}$ concentration in pasture grass is below the adequate range for supplying cattle needs. Zinc deficient concentrations in pasture grass can result from several soil factors, such as low $\mathrm{Zn}$ concentrations in soil solution, ion speciation, and the interaction of $\mathrm{Zn}$ with other macronutrients and micronutrients (Li et al., 2003). The low solubility of $\mathrm{Zn}$ in soils is the major reason for the widespread occurrence of $\mathrm{Zn}$ deficiency in plants (Das et al., 2018). In animals, deficient intake of $\mathrm{Zn}$ can result in reduced growth, loss of hair, skin lesions, and impaired reproduction due to reduced testicular development, sperm production, decrease cycling, and conception rate (Radostits et al., 2007; Spears, 1994).

The above results, expressing $\mathrm{Se}, \mathrm{Co}, \mathrm{Cu}$, and $\mathrm{Zn}$ deficiency in topsoils and pasture grass of São Miguel, are in line with the previous study of Pinto (2007a), that revealed a generalized deficiency of these essential elements in the grazing cattle of five islands of the Azores. Although this author also found a generalized deficiency of I in cattle, our study does not point to its deficiency in the environment (soil and pasture grass). Yet, I deficiency disorders may occur as cover crops containing goitrogenic plants (e.g.: white clover and brassica fodder crops) affect the I requirements of livestock by interfering with I uptake by the thyroid gland or inhibiting the synthesis of thyroxine (Bajaj et al., 2016; Chandra, 2015).

The concentrations of $\mathrm{Fe}$ in topsoils show a notable difference between the mean values observed in basaltic and trachytic soils. Such differences can be explained by the geogenic origin of these soils that result from the weathering of volcanic parent rocks with distinct geochemical compositions. Basaltic 
rocks have a higher concentration of $\mathrm{Fe}$ when compared with trachytic rocks (see Fig. 3). Regardless of these differences, the concentrations found in the topsoils of São Miguel are within the normal range and the amounts present in pasture grass are adequate to fulfill cattle needs (Mortimer et al., 1999). Therefore, no cattle health problems associated with a possible lack of Fe are expected.

As discussed above, the lack of essential elements in topsoils and/or pasture grass can have several health effects in grazing cattle. Foremost, it must be considered that farming in the Azores has a particular way of feding the animals. Although the cattle is usually outside in the grazing pastures (main feding source), dry feeds, silage, and other additives are also provided to these animals everyday to ensure an adequate intake of protein, fat, and fibers. However, in future studies it would be important to address the bioavailability and bioaccessibility of the studied essential elements to better understand their real contribution for the animals' health. The translocation factor, bioaccessibility and bioavailability factors should also be measured in the plant species that constitute the pasture grass, as the combined results from soil and grass would provide a better knowledge regarding the intake of nutrients from a natural source (pasture grass) and its potential effects in animal health. Seasonal variations were not considered in this study, since: (1) the chemical composition of the parent rocks does not change with annual seasons; (2) the climate of the Azores is temperate oceanic with no dry season (high average annual precipitation) and mild temperatures during all year (small seasonal variations when compared with continental settings); (3) the same species of pasture grass exist during all year in the sampling areas; and (4) cattle feeds on pasture grass throughout the year. Nevertheless, in other studies were these conditions are not observed, the possible seasonal variations must be considered.

Conventional farming has numerous tools to deal with essential nutrient deficiencies and/or imbalances, for example by offering complementary winter feeding and by improving pasture production with fertilizers. All of these are measures that directly or indirectly can help to maintain or even improve the animal mineral status. To assess the extent of the impact on livestock health, an integrative farm management is required, considering aspects related to soil, pasture, and animals in order to ensure adequate mineral nutrition, prevention, and mitigation of health problems associated with deficient intake of essential nutrients. As most farms currently provide forages and oral supplements to the animals, it would be important to collect blood samples (from live animals) or biological tissues (at the slaughter) to test if the observed environment deficiencies have an impact on the animal's health or whether the current management measures are sufficient to mitigate these deficiencies.

\section{Conclusions}

The compiled data of essential element concentrations in the volcanic soils of São Miguel Island have an economic and environmental relevance since it allows to assess the relationship between the geochemistry of different volcanic areas and the potential animal health issues. The results of this study evidence an uneven distribution of most of the selected essential elements ( $\mathrm{Fe}, \mathrm{Co}, \mathrm{Cu}, \mathrm{I}$, and $\mathrm{Zn}$ ) in topsoils and pasture grass of São Miguel. As these nutrients are essential for grazing cattle, their deficient availability can contribute to several health problems in the animals.

Considering the volcanic origin of São Miguel and that the pedogenesis of different volcanic parent rocks results in different soil compositions, our results pinpoint the importance of a site-by-site approach to an effective risk assessment, which takes into account the specific environmental characteristics of the soils for grazing and the impacts resulting from human activities. To further evaluate the animal health risks associated with the lack of some essential nutrients, their bioavailability and bioaccessibility, and the possible effects from seasonal variations should also be addressed in future works.

Acknowledgements Diana Linhares was supported by a postdoc fellowship from the Fundo Regional da Ciência (Regional Government of the Azores) (M3.1.a/F/004/2018).

Author contributions The authorship credit was based on the substantial contributions to conception and design, acquisition of data, or analysis and interpretation of data; the drafting the article or revising it critically for important intellectual content. All authors have read and approved the version to be submitted for publication.

Funding None. 
Declarations

Conflict of interest None.

\section{References}

Adriano, D. C. (1986). Trace elements in the terrestrial environment. Springer.

Aiuppa, A., Allard, P., D’Alessandro, W., Michel, A., Parello, F., Treuil, M., \& Valenza, M. (2000). Mobility and fluxes of major, minor and trace metals during basalt weathering and groundwater transport at Mt. Etna volcano (Sicily). Geochimica et Cosmochimica Acta, 64, 1827-1841.

Alloway, B. J. (1990). Trace metals and metalloids in soils and their bioavailability. In: Heavy metals in soils. Glasgow: Blackie Academic \& Professionals, pp 339.

Amaral, A., Cruz, J. V., Cunha, R. T., \& Rodrigues, A. (2006). Baseline levels of metals in volcanic soils of the Azores (Portugal). Soil and Sediment Contamination, 15, 123-130.

Aranalds, Ó., Bartoli, F., Buurman, P., Oskarsson, H., Stoops, G., \& García-Rodeja, E. (Eds.). (2007). Soils of volcanic regions in Europe. Springer.

Bajaj, J. K., Salwan, P., \& Salwan, S. (2016). Various possible toxicants involved in thyroid dysfunction: A review. Journal of clinical and diagnostic research, 10(1), FE01FE3.

Bargagli, R., Barghigiani, C., Siegel, B. Z., \& Siegel, S. M. (1991). Trace metal anomalies in surface soils and vegetation on two active island volcanoes: Stromboli and Vulcano (Italy). Science of the Total Environment, 102, 209-222.

Beier, C., Stracke, A., \& Haase, K. M. (2007). The peculiar geochemical signatures of São Miguel (Azores) lavas: Metasomatised or recycled mantle sources? Earth and Planetary Science Letters, 259, 186-199.

Chandra, A. K. (2015). Iodine, thiocyanate and the thyroid. Biochemical Pharmacology, 4, 171.

Chazarra, A., Mestre, A., Pires, V., Cunha, S., Silva, A., Marques, J., et al. (2011). Climate Atlas of the archipelagos of the Canary Islands, Madeira and the Azores. Agencia Estatal de Meteorología Ministerio de Agricultura, Alimentación y Medio Ambiente. Instituto de Meteorologia de Portugal.

Coulter BS. and Lalor S. (2008). Major and micro nutrient advice for productive agricultural crops. 3rd edition. Teagasc, Johnstown Castle, Wexford. pp.116.

Cropper, T. (2013). The weather and climate of Macaronesia: past, present and future. Weather, 68(11), 300-307.

Cruz, J. V., Coutinho, R. M., Rosário Carvalho, M., Oskarsson, N., \& Gislason, S. R. (1999). Chemistry of waters from Furnas volcano, São Miguel, Azores: Fluxes of volcanic carbon dioxide and leached material. Journal of Volcanology and Geothermal Research, 92, 151-167.

Dangour, A. D., Allen, E., Clarke, R., Elbourne, D., Fletcher, A. E., Letley, L., et al. (2015). Effects of vitamin B-12 supplementation on neurologic and cognitive function in older people: A randomized controlled trial. American Journal of Clinical Nutrition, 102, 639-647.
Dargatz, D. A., Garry, F. B., Clark, G. B., \& Ross, P. F. (1999). Serum copper concentrations in beef cows and heifers. American Journal of Veterinary Research, 215, 1828-1832.

Das, S. K., Avasthe, R. K., Singh, M., Dutta, S. K., \& Roy, A. (2018). Zinc in plant-soil system and management strategy. A ̌rr , 7(1), 1-6.

Djoko, K. Y., Ong, C. L., Walker, M. J., \& McEwan, A. G. (2015). The role of copper and zinc toxicity in innate immune defense against bacterial pathogens. The Journal of biological chemistry, 290(31), 18954-18961.

Doelsch, E., Kerchove, V. V., \& Macary, H. S. (2006). Heavy metal concentration in soils of Reunion (Indian Ocean). Geoderma, 134, 119-134.

Ehrmann, J., \& Ritz, K. (2014). Plant: soil interactions in temperate multi-cropping production systems. Plant and Soil, 376, 1-29.

Eswaran, H., Van Den Berg, E., \& Reich, P. (1993). Organic carbon in soils of the world. Soil Science Society of America Journal, 57, 192-194.

Fordyce, F. (2005). Selenium deficiency and toxicity in the environment. In O. Selinus, B. Alloway, J. A. Centeno, R. B. Finkleman, R. Fuge, U. Lindh, \& P. Smedley (Eds.), Essentials of medical geology, impact of the natural environment on public health. Elsevier Academic Press.

Freitas, M. C., \& Pacheco, A. M. G. (2010). Soils of Azores islands: Elemental characterization with an emphasis on rare-earth elements. Journal of Radioanalytical and Nuclear Chemistry, 283, 117-122.

Gaspar, J. L., Guest, J. E., Queiroz, G., Pacheco, J., Pimentel, A., Gomes, A., et al. (2015). Eruptive frequency and volcanic hazards zonation in São Miguel Island, Azores. In J. L. Gaspar, J. E. Guest, A. M. Duncan, F. J. A. S. Barriga, \& D. K. Chester (Eds.), Volcanic Geology of São Miguel Island (Azores Archipelago). Geological Society.

Gawlick, B., \& Bidoglio, G. (2006). Background values in European soils and sewage sludges. Luxembourg: office for Official Publications of the European Communities.

EuroGeoSurveys Geochemical mapping of agricultural and grazing land soil of Europe (GEMAS) - Field manual. (2008). NGU Report 2008.038.

Grace, N. D. (1994). Managing trace element deficiencies. New Zealand Pastoral Agricultural Institute Ltd.

Gupta, U. C., \& Gupta, S. C. (2002). Quality of animal and human life as affected by selenium management of soils and crops. Communications in Soil Science and Plant Analysis, 33(15-18), 2537-2555.

Hernández, A., Kutiel, H., Trigo, R. M., Valente, M. A., Sigró, J., Cropper, T., \& Santo, F. E. (2016). New Azores Archipelago daily precipitation dataset and its links with large-scale modes of climate variability. International Journal of Climatology, 36, 4439-4454.

IBM SPSS 26.0. (2019). IBM SPSS Statistics 25 Core System User's Guide, USA.

Jackson, M. L. (1958). Soil chemical analysis (p. 498). Prentice Hall, Inc.

Jeffery, A. J., Gertisser, R., O'Driscoll, B., Pacheco, J. M., Whitley, S., Pimentel, A., \& Self, S. (2016). Temporal evolution of a post-caldera, mildly peralkaline magmatic system: Furnas volcano, São Miguel. Azores. Contributions to Mineralogy and Petrology, 171, 42. 
Judson, G. J., \& McFarlane, J. D. (1998). Mineral disorders in grazing livestock and the usefulness of soil and plant analysis in the assessment of these disorders. Australian Joumal of Expertmental Agiculture, 38, 707-723.

Kabata-Pendias, H. (2011). PENDIAS, H. Trace elements in Soils and Plants. CRC Press p. 534.

Kelepertsis, A., Alexakis, D., \& Kita, I. (2001). Environmental geochemistry of soils and waters of Susaki area, Korinthos, Greece. Environmental Geochemistry and Health, 23, 117-135.

Kreplin, C. \& Yaremcio, B. (1992) Effects of nutrition on beef cow reproduction. Agdex 420/51-1.

Lark, R. M., Ander, E. L., Cave, M. R., Knights, K. V., Glennon, M. M., \& Scanlon, R. P. (2014). Mapping trace element deficiency by cokriging from regional geochemical soil data: A case study on cobalt for grazing sheep in Ireland. Geoderma, 226-227, 64-78.

Le Bas, M. J., Le Maitre, R. W., Streckeisen, A., \& Zanettin, B. (1986). A chemical classification of volcanic rocks based on the total alkali-silica diagram. Journal of Petrology, 27(3), 745-750.

Li, H. Y., Zhu, Y. G., Smith, S. E., \& Smith, F. A. (2003). Phosphorus-zinc interactions in two barley cultivars differing in phosphorus and zinc efficiencies. Journal of Plant Nutrition, 26, 1085-1099.

Linhares, D., Garcia, P., Almada, A., Ferreira, T., Queiroz, G., Cruz, J. V., \& Rodrigues, A. S. (2015). Iodine environmental bioavailability and human intake in oceanic islands: Azores as a case study. Science of the Total Environment, 538, 531-538.

Linhares, D., Pimentel, A., Borges, C., Cruz, J. V., Garcia, P., \& Rodrigues, A. (2019). Cobalt distribution in the soils of São Miguel Island (Azores): From volcanoes to health effects. Science of the Total Environment, 684, 715-721.

López-Alonso, M. (2012). Trace minerals and livestock: not too much not too little. ISRN Veterinary Science, 704825.

Madeira, M., Pinheiro, P., Madruga, J., \& Monteiro, F. (2007). Soils of volcanic systems in Portugal. In F. Bartoli, P. Buurman, O. Arnalds, G. Stoops, \& E. Garcia-Rodeja (Eds.), Soils of volcanic regions of Europe. Springer.

Marescotti, P., Comodi, P., Crispini, L., Gigli, L., Zucchini, A., \& Fornasaro, S. (2019). Potentially toxic elements in ultramafic soils: a study from metamorphic ophiolites of the Voltri Massif (Western Alps, Italy). Minerals, 9(8), 502.

Mattioli, G. A., Ramirez, C. E., Giuliodori, M. J., Tittarelli, C. M., Yano, H., \& Matsui, T. (1996). Characterization of cattle copper deficiency in the Magdalena district. Livestock Production Science, 47, 7-10.

McDowell, L. R. (1985). Nutrition of grazing ruminants in warm climates. Academic Press Inc.

McDowell, L. R. (2003). Minerals in animal and human nutrition (2nd ed., pp. 235-276). University of Florida.

Meglia, G. E. (2004), Doctoral Thesis, Nutrition and Immune Response in Periparturient Dairy Cows. Swedish University of Agricultural Sciences.

Molnar, J., Macpherson, A., \& Molnar, P. (1998). The effects of selenium supplementation in feeding of lambs. Acta Alimentaria, 24, 167-179.

Mortimer, R. G., Dargatz, D., A. Corah, L. R. (1999). Forage Analyses from Cow-Calf Herds in 23 States.
USDAAPHIS:VS, Centers for Epidemiology and Animal Health. Fort Collins, CO. \#N303.499.

National Research Council (US). (2001). Dairy cattle - Nutrition-Requirements.7th rev. ed. ISBN 0-309-06997-1 1. 2. Dairy cattle-Feeding and feeds. I. (U.S.). Subcommittee on Dairy Cattle Nutrition.

Neall, V. E. (2006). Volcanic soils. In W. Verheye (Ed.), Land use and land cover Encyclopaedia of Life Support Systems (EOLSS). EOLSS publishers with UNESCO.

Nelson, D. W., Sommers, L. E. (1982). Total carbon, organic carbon and organic matter. A.L. Page, et al. (Eds.), Methods of Soil Analysis: Part. 2. Chemical and Microbiological Properties (2nd edition), Agronomy Monograph, vol. 9, America Soc. of Agronomy \& Soil Science Soc. of America Inc., Madison, pp. 539-579.

Neta, A. B. F., do Araújo-Nascimento, C. W., Biondi, C. M., van Straaten, P., \& Bittar, S. M. B. (2018). Natural concentrations and reference values for trace elements in soils of a tropical volcanic archipelago. Environmental Geochemistry and Health, 40, 163-173.

Pacheco, J. M., Ferreira, T., Queiroz, G., Wallenstein, N., Coutinho, R., Cruz, J. V., et al. (2013). Notas sobre a geologia do arquipélago dos Açores. In R. Dias, A. Araújo, P. Terrinha, \& J. C. Kullberg (Eds.), Geologia de Portugal (Vol. 2, pp. 595-690). Escolar Editora.

Parelho, C., Rodrigues, A. S., Cruz, J. V., \& Garcia, P. (2014). Linking trace metals and agricultural land use in volcanic soils: A multivariate approach. Science of the Total Environment, 496, 241-247.

Pavlata, L., Podhorsky, A., Pechova, A., \& Chomat, P. (2005). Differences in the occurrence of selenium, copper and zinc deficiencies in dairy cows, calves, heifers, and bulls. Veterinary Medicine, 50, 390-400.

Peers, D. \& Phillips, K. (2011). Trace elemento supplementation of beef cattle and sheep development board (AHDB) AHDB beef $\&$ lamb is a division of the agriculture \& horticulture. AHDB Beef \& Lamb Stoneleigh Park Kenilworth Warwickshire CV8 2TL. 1-19.

Pimentel, A., Zanon, V., De Groot, L. V., Hipólito, A., Di Chiara, A., \& Self, S. (2016). Stress-induced comenditic trachyte effusion triggered by trachybasalt intrusion: multidisciplinary study of the AD 1761 eruption at Terceira Island (Azores). Bulletin of Volcanology, 78(3), 22.

Pinto, C., Viana, J., \& Aranha, P. (2007a). Carências em oligoelementos em bovinos dos Açores. VII Encontro da Sociedade Portuguesa de Epidemiologia e Medicina Veterinária Preventiva.

Pinto, C., Viana, J., \& Aranha, P. (2007b). Avaliação do efeito da administração de oligoelementos no crescimento de novilhos. VII Encontro da Sociedade Portuguesas de Epidemiologia e Medicina Veterinária Preventiva.

Porreca, M., Pimentel, A., Kueppers, U., Izquierdo, T., Pacheco, J., \& Queiroz, G. (2018). Event stratigraphy and emplacement mechanisms of the last major caldera eruption on Sete Cidades Volcano (São Miguel, Azores): the 16 ka Santa Bárbara Formation. Bulletin of Volcanology, 80, 76.

Prasad, C. S., Arora, S. P., Prasad, T., Chabra, A., Ibrahim, M. N. M. (1995). Mineral requirements and straw feeding systems. Hand Book for Straw Feeding Systems, (ICAR, New Delhi), 225-238. 
Queiroz, G. (1997). Vulcão das Sete Cidades (S. Miguel, Açores): História eruptiva e avaliação do hazard. $\mathrm{PhD}$ thesis. Universidade dos Açores - Departamento de Geociências (226 pp).

Radostits, O. M., Gay, C. C., Blood, D. C., Hinchliff, K. W. (2007). Veterinary Medicine. A textbook of the diseases of cattle, sheep, goats and horses.10th (ed.), WB Saunders Co. Pp: 1730-1733.

Rawlins, B. G., McGrath, S. P., Scheib, A. J., Breward, N., Cave, M., Lister, T. R., et al. (2012). The advanced soil geochemical atlas of England and Wales. British Geological Survey.

Ricardo, R. P., Madeira, M., Medina, J. M. B., Marques, M. M., \& Furtado, A. F. S. (1977). Esboço pedológico da ilha de S. Miguel (Açores). Anais do Instituto Superior de Agronomia, 37, 275-385.

Salminen, R., Batista, M. J., Bidovec, M., Demetriades, A., deVivo, B., de Vos, W., et al. (2005). Geochemical atlas of Europe. Part 1: background information, methodology and maps. Espoo: Geological Survey of Finland.

Senesi, G. S., Baldssarre, G., Senesi, N., \& Radina, B. (1999). Trace element inputs into soil by anthropogenic activities and implication for human health. Chemosphere, 39(2), 343-377.

Spears, J. W. (1994). Minerals in forages. In G. C. Fahey Jr. (Ed.), Forge quality, evaluation, and utilization. American Society of Agronomy Inc.

Surai, P. F. (2006). Selenium in nutrition and health. Nottingham University Press.

Suttle, N. F. (2010). Mineral nutrition of livestock (4th ed.). CABI.

Tepe, N., \& Bau, M. (2014). Importance of nanoparticles and colloids from volcanic ash for riverine transport of trace elements to the ocean: Evidence from glacial-fed rivers after the 2010 eruption of Eyjafjallajökull Volcano Iceland. Science of The Total Environment., 488-489C(1), 243-251.
Thornton, I., \& Alloway, B. J. (1974). Geochemical aspects of the soil-plant-animal relationship in the development of trace element deficiency and excess. British Journal of Nutrition, 33, 257-266.

Torre, P. M., Harmon, R. J., Hemken, R. W., Clark, T. W., Trammell, D. S., \& Smith, B. A. (1996). Mild dietary Cu sufficient depresses blood neutrophil function in dairy cattle. Journal of Nutritional Immunology, 4(3), 3-24.

Tun, A. M., Thein, K. Z., Myint, Z. W., \& Oo, T. H. (2017). Pernicious anemia: fundamental and practical aspects in diagnosis. Cardiovascular \& Hematological Agents in Medicinal Chemistry, 15(1), 17-22.

Wallenstein, N. (1999). Estudo da história recente e do comportamento eruptivo do Vulcão do Fogo (S. Miguel, Açores). Avaliação preliminar do hazard. $\mathrm{PhD}$ thesis. Universidade dos Açores - Departamento de Geociências (266 pp).

WHO. (1996). Permissible limits of heavy metals in soil and plants. Geneva.

WHO. (1998). Quality control method for medicinal plant materials. Geneva.

Yadav, M. K., Manoli, N. M., \& Madhunapantula, S. V. (2016). Comparative assessment of vitamin-B12, folic acid and homocysteine levels in relation to p53 expression in megaloblastic anemia. PLoS ONE, 11(10), e0164559.

Zanon, V. (2015). Conditions for mafic magma storage beneath fissure zones at oceanic islands: The case of São Miguel island (Azores archipelago) . In L. Caricchi \& J. D. Blundy (Eds.), Chemical physical and temporal evolution of magmatic systems. Geological Society.

Publisher's Note Springer Nature remains neutral with regard to jurisdictional claims in published maps and institutional affiliations. 